\title{
Self-medication with oral contraceptives in the Urban District of Antananarivo
}

\author{
Julio El-C Rakotonirina, Manitatsoa Razafimahefa, Barbara E.E. Vololonarivelo*, Valéry B. \\ Andriantoky, Mamy J-J Razafimahatratra, Jean de Dieu M. Rakotomanga, Henriette \\ Rahantalalao Ratsimbazafimahefa, Nantenaina S. Randrianjafisamindrakotroka
}

Faculté de Médecine d'Antananarivo. P.O Box 375 Antananarivo 101, Madagascar

Received: 24 January 2014

Accepted: 2 February 2014

*Correspondence:

Dr. Barbara E.E. Vololonarivelo,

E-mail: barbara1elyan@gmail.com

(C) 2014 Rakotonirina JEC et al. This is an open-access article distributed under the terms of the Creative Commons Attribution Non-Commercial License, which permits unrestricted non-commercial use, distribution, and reproduction in any medium, provided the original work is properly cited.

\begin{abstract}
Background: Oral contraception is the second hormonal contraceptive method most used in the world. Currently, self-medication with oral contraceptives experienced resurgence, most often with no medical supervision. This study aims to estimate the prevalence of self-medication with oral contraceptives, identify the socio-economic status and identify the reasons why women aged 21 to 49 of the Urban District of Antananarivo (UDA) practice self-medication with oral contraceptives.

Methods: A cross-sectional survey was conducted, where an interviewer-administered questionnaire has been used to collect data. Targeted female respondents aged 21-49 were asked about their contraceptive use during the twelve months preceding the survey.

Results: Self-medication prevalence rate is $59.1 \%$, considering oral contraception users. Moreover, it is higher among married women, those aged $<36$, less educated and having more than two children. Financial problem, affordability of the pills, former use of pills and information by their surroundings are the reasons why women self-medicate. Women who received a medical prescription at the first take of the pills are more likely to presently practice self-medication.

Conclusions: This study demonstrates the evidence of a high prevalence of self-medication in the UDA. Selfmedication can be harmful: the fight against its risks should get reinforced.
\end{abstract}

Keywords: Self-medication, Oral contraceptive, Urban District, Antananarivo

\section{INTRODUCTION}

Oral contraception is the second hormonal contraceptive method most used in the world. ${ }^{1}$ In Madagascar, women can get birth control pills without prescription in pharmacies. ${ }^{2}$ The Reproductive Health Standards and Procedures defines self-medication as not to see family planning providers at the beginning of the medication, or lack of medical checks three months after the first dose and/or 12 months after the first visit (Community Officer, paramedics, physicians in Madagascar). ${ }^{3}$ Two forms of self-medication in oral contraceptives are recognized: the purchase of oral contraceptives without a prescription, and the absence of medical checks three months after the first dose or every 12 months from the fourth plate. ${ }^{2,4}$ Currently, self-medication in oral contraceptives experienced resurgence, as in many countries of the world, ${ }^{5}$ Africa, ${ }^{6}$ Madagascar, and in the pharmacies of the Urban District of Antananarivo (UDA), most often with no medical supervision. No prevalence was specified in the study explaining the case of the UDA. ${ }^{2}$

In Kuwait, the reasons for this attitude are the affordability and accessibility of contraceptive pills in pharmacies. ${ }^{5}$ 
Clear instructions on the leaflet and the use of a medical list were proposed. These help women identify themselves the contra-indications, to ensure their safety and the effectiveness of pills, to improve their access to oral contraceptives. ${ }^{7}$ However, this is not obvious to the Malagasy as $20 \%$ of women have no education and only $5 \%$ of the population has reached a complete primary education in 2009. ${ }^{8}$ The risk of adverse effects and unwanted pregnancies would be high. In the UDA, the problem is related to the determination of the factors that influence self-medication with oral contraceptives among women aged 21 to 49 .

This study aims to (i) estimate the prevalence of selfmedication with oral contraceptives, (ii) determine the socio-economic profile of women who self-medicate and (iii) identify the reasons why women aged 21 to 49 of the UDA practice self-medication with oral contraceptives.

\section{METHODS}

\section{Study site}

The Urban District of Antananarivo is the administrative capital of Madagascar. It covers an area of $78.7 \mathrm{~km}^{2}$ with 6 districts divided into 192 fokontany (smallest administrative divisions). Within 10 years, the population was multiplied by $1.4 .^{8}$

The overall total fertility rate is 94 per 1,000 women; the crude birth rate was 24.4 per 1,000 women with $99.9 \%$ of women aged 15 to 49 experiencing a contraceptive method and $8.5 \%$ taking oral contraceptives. ${ }^{9}$

In 2011, studies on self-medication were conducted in the capital. Oral contraceptives are among the drugs used for self-medication, but its extent is not determined. ${ }^{2}$

\section{Study period}

A retrospective cross-sectional study was conducted to determine the extent of self-medication in oral contraceptives during the last 12 months before the survey, the socio-economic status of women who resort to this practice, and to identify the reasons that could explain this practice. The study period runs from November 2011 to October 2012.

\section{Population}

We included all women aged 21 to 49, of Malagasy nationality, having lived for more than a year in a fokontany of the UDA, legally able and willing to participate in the survey.

\section{Sampling mode}

In this survey, the sampling is done by a two-stage cluster. Fokontany in the six districts of the UDA are classified as first degree clusters. Households in fokontany form second degree clusters. The minimum size of households covering the set of all women aged 21 to 49 in the UDA is $n=180$. Of the 30 selected fokontany, at least 6 households per fokontany were surveyed. In each household, we interviewed women aged 21 to 49 .

\section{Variables}

We studied two dependent variables: the duration of oral contraception and the reasons for self-medication. The non-dependant variables are the socioeconomic parameters, the parameters related oral contraception, and the contraceptive methods previously used.

\section{Data management and statistical analysis}

The questionnaire was developed with Epi-info 7. The survey results were processed using Epi-info 7 and Microsoft Excel softwares. In this study, the chi-square test is used to calculate the p-value in order to identify any significant differences in the variables studied between practice and non-practice of self-medication.

\section{RESULTS}

\section{General description of the participants}

At the end of the survey, 232 women aged 21 to 49 participated. The contraceptive use rate is $81 \% ; 19 \%$ of the participants did not use contraceptives. In total, oral contraceptives users represent $18.9 \%$, whether or not alternating with injectables or implants during the last 12 months preceding the survey $(14.2 \%$ with oral contraceptives only). Temporary contraception appears to be the most used, as $85.6 \%$ of the women practice it. Among these women practicing temporary contraception, $27.3 \%$ (n $=44$ ) use oral contraception: $40.9 \%$ of them $(n=18)$ have a consistent medical prescription while $59.1 \% \quad(\mathrm{n}=26)$ practice self-medication with oral contraceptives. Ninetytwo percent of women who practice self-medication with oral contraceptives tend to choose PILPLAN ${ }^{\circledR}$. The rest takes MICROGYNON ${ }^{\circledR}$ and LO-FEMENAL ${ }^{\circledR}$.

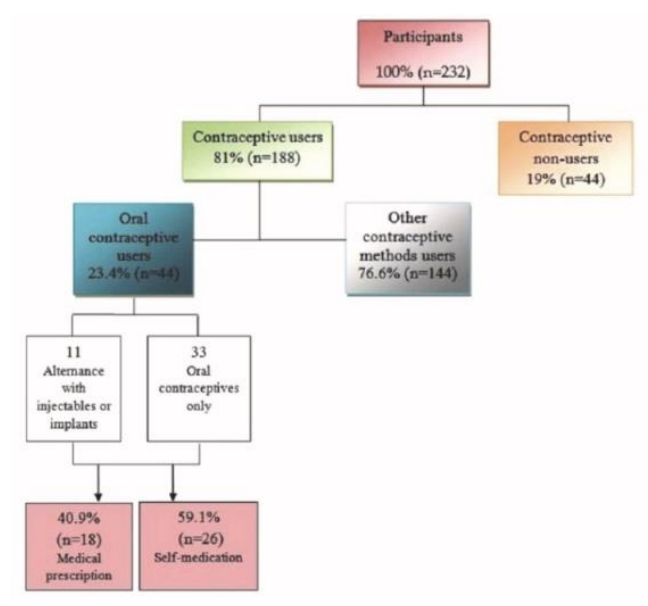

Figure 1: Distribution of contraception use among participants in the UDA. 


\section{Self-medication with oral contraceptives}

a. Socio-economic status of women aged 21 to 49 practicing self-medication in oral contraceptives in the $U D A$.

Women aged 26 to 30 make up $23.28 \%$ of the participants. Women aged 46 to 49 were the least likely to participate in the survey because they only represent $6.0 \%$ of the participants. Among the participants, $1.3 \%$ (n $=2$ ) were never educated. Women of high school level are the most numerous $(45.7 \%)$.

Table 1: Socio-economic status of women selfmedication with oral contraceptives.

\begin{tabular}{|c|c|c|c|c|c|}
\hline & \multicolumn{5}{|c|}{ Socio-economic status } \\
\hline & \multicolumn{2}{|c|}{$\begin{array}{l}\text { Self } \\
\text { medication }\end{array}$} & \multicolumn{2}{|c|}{ Prescription } & \multirow[t]{2}{*}{$p$-value } \\
\hline & $\mathrm{n}$ & $\%$ & $\mathrm{n}$ & $\%$ & \\
\hline Marital status & & & & & 0.35 \\
\hline Married & 25 & 61 & 16 & 39 & \\
\hline Not married & 1 & 33.3 & 2 & 66.7 & \\
\hline Education & & & & & 0.53 \\
\hline None & 2 & 100 & 0 & 0 & \\
\hline Primary & 8 & 53.3 & 7 & 46.7 & \\
\hline Secondary & 12 & 63.2 & 7 & 36.8 & \\
\hline High school & 4 & 57.1 & 3 & 42.9 & \\
\hline University & 0 & 0 & 1 & 100 & \\
\hline Occupation & & & & & 0.63 \\
\hline Without & 9 & 64.3 & 5 & 35.7 & \\
\hline With some & 17 & 56.7 & 13 & 43.3 & \\
\hline Monthly income & & & & & 0.61 \\
\hline $\begin{array}{l}\text { Less than } 50,000 \\
\text { MGA* }\end{array}$ & 19 & 63.3 & 11 & 36.7 & \\
\hline $\begin{array}{l}\text { More than } \\
50,000 \mathrm{MGA}^{*}\end{array}$ & 7 & 53.8 & 6 & 46.2 & \\
\hline $\begin{array}{l}\text { Not willing to } \\
\text { answer }\end{array}$ & 1 & 100 & 0 & 0 & \\
\hline
\end{tabular}

*MGA: MalaGasy Ariary (Malagasy currency)

b. Reasons why women aged 21 to 49 of the UDA practice self-medication with oral contraceptives.

Over $60 \%$ of women who have previously used other contraceptive methods currently practice self-medication in oral contraceptives. Sixty-one point one percent of women using birth control pills who perceived side effects with their old method currently practice selfmedication with oral contraceptives.

Table 2: Reasons related to former use and knowledge of side/adverse effects of contraceptives.

\begin{tabular}{|c|c|c|c|c|c|}
\hline & \multicolumn{2}{|c|}{$\begin{array}{l}\text { Self } \\
\text { medication }\end{array}$} & \multicolumn{2}{|c|}{ Prescription } & \multirow[t]{2}{*}{$\begin{array}{l}p- \\
\text { value }\end{array}$} \\
\hline & $n$ & $\%$ & $n$ & $\%$ & \\
\hline $\begin{array}{l}\text { Perceived adverse } \\
\text { effects of former } \\
\text { method }\end{array}$ & & & & & 0.36 \\
\hline Yes & 11 & 61.1 & 7 & 38.9 & \\
\hline \multicolumn{6}{|l|}{ No } \\
\hline Know adverse effects & & & & & 0.47 \\
\hline Yes & 12 & 60 & 8 & 40 & \\
\hline No & 14 & 58.3 & 10 & 41.7 & \\
\hline $\begin{array}{l}\text { Ability to list } \\
\text { side effects }\end{array}$ & & & & & 0.78 \\
\hline Cancer of the cervix & 1 & 100 & 0 & 0 & \\
\hline Dysmenorrhea & 1 & 66.7 & 2 & 33.3 & \\
\hline Stomach pain & 3 & 60 & 2 & 40 & \\
\hline Hypertension & 2 & 50 & 2 & 50 & \\
\hline Asthenia & 1 & 50 & 1 & 50 & \\
\hline Migraine & 4 & 100 & 0 & 0 & \\
\hline Vertigo & 6 & 85.7 & 1 & 14.3 & \\
\hline Alopecia & 1 & 50 & 1 & 50 & \\
\hline Blurred vision & 1 & 100 & 0 & 0 & \\
\hline Metrorrhagia & 1 & 100 & 0 & 0 & \\
\hline Nausea & 0 & 0 & 1 & 100 & \\
\hline Dyspnea & 0 & 0 & 1 & 100 & \\
\hline $\begin{array}{l}\text { Will to have more } \\
\text { children }\end{array}$ & & & & & 0.63 \\
\hline Yes & 9 & 64.3 & 5 & 35.7 & \\
\hline No & 17 & 56.7 & 13 & 43.3 & \\
\hline Place of supply & & & & & 0.06 \\
\hline Grocery & 3 & 75 & 1 & 25 & \\
\hline Pharmacy & 15 & 78.9 & 4 & 21.1 & \\
\hline Family physician & 2 & 66.7 & 1 & 33.3 & \\
\hline Clinic & 1 & 50 & 1 & 50 & \\
\hline Basic Health Center II & 2 & 20 & 8 & 80 & \\
\hline Infirmary & 3 & 75 & 1 & 25 & \\
\hline Public hospital & 0 & 0.0 & 1 & 100 & \\
\hline $\begin{array}{l}\text { Family planning } \\
\text { center }\end{array}$ & 0 & 0.0 & 1 & 100 & \\
\hline \multicolumn{6}{|l|}{ Prescriber } \\
\hline Physician & 15 & 68.2 & 7 & 32.8 & 0.22 \\
\hline Midwives & 2 & 100 & 0 & 0 & \\
\hline Other & 0 & 0 & 1 & 100 & \\
\hline
\end{tabular}


Women who practice self-medication in oral contraceptives are more informed about the existence of the side effects of these pills $(60 \%)$ than those with prescriptions $(40 \%)$.

Women practicing self-medication represent $78.9 \%$ of women who buy their pills in pharmacies, three-quarters in grocery stores and clinics. Only a minority (20\%) of women who have the Basic Health Center II as a source of oral contraceptives practice self-prescription.

The majority of women who are new to the world of contraception chose the medical prescription $(58.3 \%$ versus $41.7 \%, p=0.15)$. Most of women who have received a medical prescription did not undergo medical checks $(68.2 \%)$. Regarding midwives, none of their patients underwent medical checks.

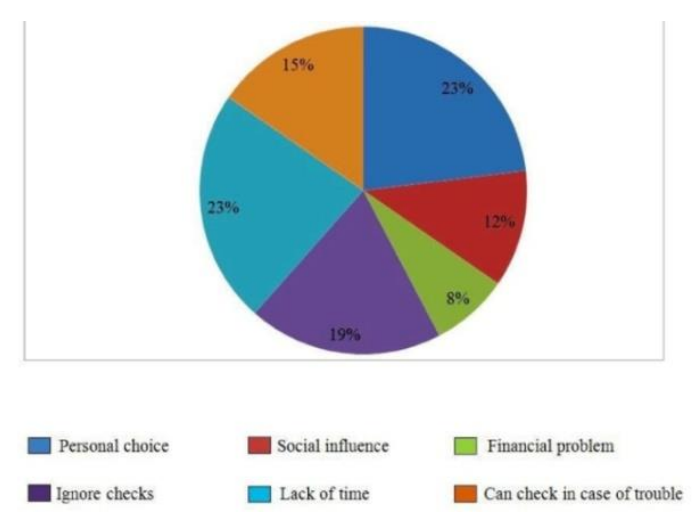

Figure 2: Identification of the reasons why women aged 21 to 49 presently self-medicate with oral contraceptives in the UDA.

Among working women, $29.4 \%$ practice self-medication with oral contraceptives while disregarding the need to make regular checks. Only $5.9 \%$ of women in this group referred to some financial problem as an obstacle to the medical prescription of oral contraceptives. Regarding housewives, $50 \%$ decided to practice self-medication with oral contraceptives because it is their personal choice.

\section{DISCUSSION}

\section{Prevalence of self-medication with oral contraceptives at the UDA, socio-economic status}

The prevalence of self-medication in oral contraceptives is high with a rate of $59.1 \%$. This prevalence is similar to that of urban districts of Kuwait which is $57.4 \% .^{5}$ A similar behavior of townsfolk could explain this similarity in both urban areas. Pilplan ${ }^{\circledR}$ is the most widely used pill for selfmedication. It is distributed as part of a social marketing strategy, in collaboration with the National Progamme which aims to control births. ${ }^{10}$ Microgynon ${ }^{\circledR}$ and LoFemenal $^{\circledR}$ are available in public health centers only, which explains their low use in self-medication.
Younger women are more likely to self-medicate (with pills as with other methods), as stated by the National Institute of Statistics in 1997: ${ }^{11}$ older women are more likely to reject and abandon contraception. Similarly, self-medication is important among housewives (64.3\%). This approximates that of Kuwait $(63.7 \%) .^{5}$ The access of small income to health care is difficult, ${ }^{11}$ which favors self-medication in Antananarivo. Medical consultations and repeated checks prove to be useless because they are considered as restrictions to the monthly budget. On the other hand, women who work do not have time to consult doctors: their absence from work affects their income. This could also be true for high school women who selfmedicate as most of them work.

\section{Reasons for self-medication with oral contraceptives}

The availability of pills in grocery stores and pharmacies encourages women to self-medicate. In Mali, the illegal sales reinforce self-medication. ${ }^{12}$ The Texans cross the border to buy their pills in Mexican pharmacies where prices are more affordable and medical prescriptions are non-mandatory requirements. ${ }^{13}$ This study found that selfmedication is more common in women who have used pills during a longer period. Potter also reported the same fact in Mexico. ${ }^{6}$ The assistance of a health professional could be overlooked because women might think of themselves as already experienced. Moreover, they did not feel any side effects during long periods of use.

\section{CONCLUSION}

Self-medication with oral contraceptives in the UDA is important. The knowledge gained through this study help to improve the government information, education and communication for behavior change programs. These programs educate women to regularly consult family planning providers.

The validity of this study in rural towns and other urban districts in Madagascar is a limit. To update the recorded data, the study should be repeated every five years in different Malagasy districts.

Looking ahead, studies on the difference in the efficacy, adverse effects and continuity of oral contraception among women who receive medical prescription and women practicing self-medication should be made.

Funding: None

Competing interests: None declared

Ethical approval: Not required

\section{REFERENCES}

1. United Nations. Contraceptive prevalence by methods, most recent estimate, World contraceptive use 2009. New York, 2009. Available at http://www.un.org/esa/population/publications/contr 
aceptive2009/contracept2009_wallchart_front.pdf.

Accessed 15 February 2012.

2. Rahelinjanahary V. Importance de l'automédication en milieu urbain et milieu rural à Antananarivo et ses environs. Antananarivo: Thèse Pharmacie, 2011; $\mathrm{N}^{\circ} 0012: 1-51$.

3. Ministère de la santé et du planning familial. Normes et Procédures en Santé de la Reproduction.

4. Potter JE, McKinnon S, Hopkins K, Amastae J, Shedlin MG, Powers DA, Grossman D. Continuation of prescribed compared with over-thecounter oral contraceptives. Obstet Gynecol 2011;117:551-7.

5. Shah MA, Shah NM, Al-Rahmani E, Bebehani J, Radovanovic Z. Over-the-counter use of oral contraceptives in Kuwait. Int $\mathrm{J}$ Gynaecol Obstet 2001;73:243-51.

6. Dembélé RD. Etude descriptive de la vente illicite des médicaments dans les marchés des communes de Kimparana, de Karaba et Kassorola. Bamako. Thèse Pharmacie, 2005; $\mathrm{N}^{\circ}$ 05P42:1-54.

7. Grossman D, White K, Hopkins K, Amastae J, Shedlin M, Potter JE. Contraindications to combined oral contraceptives among over-thecounter compared with prescription users. Obstet Gynecol 2011;117:558-65.

8. INSTAT, ICF Macro. Enquête démographique et de santé de Madagascar 2008-2009. Antananarivo,
Madagascar: INSTAT et ICF Macro, $4^{\text {th }}$ ed. Antananarivo: INSTAT et ICF Macro; 2010:27.

9. INSTAT, ICF Macro. Planification familiale. In: Enquête démographique et de santé de Madagascar 2008-2009. 4th ed. Antananarivo: INSTAT et ICF Macro; 2010:63-78.

10. PSI. Madagascar (2010-2011): MAP Study Evaluating the Availability of Pilplan and Confiance in Madagascar. Baseline. Available at http://www.psi.org/resources/researchmetrics/publications/reproductivehealth/madagascar-2010-2011-map-study-evaluatin. Accessed 25 April 2012.

11. Castro-Leal F, Dayton J, Demery L, Mehra K. Public Social Spending in Africa: Do the Poor Benefit? The World Bank Research Observer1999;14:49-72.

12. Mathieu Lamiaux, François Rouzaud, Wendy Woods. Private Health Sector Assessment in Mali. The Post-Bamako Initiative Reality. In: World Bank Working Paper $N^{\circ} 212$. Washington, DC: The World Bank. 2011:127.

13. Grossman D, Fernández L, Hopkins K, Amastae J, Potter JE. Perceptions of the safety of oral contraceptives among a predominantly Latina population in Texas. Contraception 2010;81:254-60.

DOI: $10.5455 / 2320-1770 . i j r \operatorname{cog} 20140304$

Cite this article as: Rakotonirina JEC, Razafimahefa M, Vololonarivelo BEE, Andriantoky VB, Razafimahatratra MJJ, Rakotomanga JDM, Ratsimbazafimahefa HR, Randrianjafisamindrakotroka NS. Self-medication with oral contraceptives in the Urban District of Antananarivo. Int J Reprod Contracept Obstet Gynecol 2014;3:26-30. 